\title{
前立腺乳頭状腺癌の臨床的検討
}

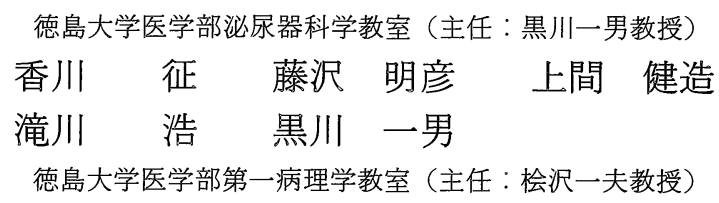

佐 野 着 昭
小松島赤十字病院泌尿器科 (部長 : 桜井紀嗣)
桜 井 紀 嗣

\section{PAPILLARY ADENOCARCINOMA OF THE PROSTATE}

\author{
Susumu Kagawa, Akihiko Fujisawa, Kenzo Uema, Hiroshi Takigawa and Kazuo Kurokawa \\ Department of Urology, School of Medicine, Tokushima University \\ (Director: Prof. K. Kurokawa) \\ Toshiaki Sano \\ Department of 1st Pathology, School of Miedicine, Tokushima University \\ (Director: Prof. K. Hizawa) \\ Noritsugu Sakurai \\ Department of Urology, Komatsushima Red Cross Hospital
}

(Director: N. Sakurai)

Five cases of papillary adenocarcinomas of the prostate were studied for the clinical features, histologic characteristics and immunohistochemical nature of prostatic specific antigen, and one case of them was studied by electron microscopy.

Our results, as well as those presented previously, demonstrate the prostatic origin of this tumor, and these lesions should be called "Prostatic ductal adenocarcinoma with endometrioid features". In accordance with the observations of other authors, antiandrogen therapy for these patients was considered justifiable.

\footnotetext{
要旨：5 例の前立腺乳頭状腺癌について臨床所見, 組織学的所見, 前立腺特異抗原 (PSA) に対する免 疫組織学的所見について検討し，らち1例に扔いては電顕的所見も検討した.

PSA は全例に染色され，これらの乳頭状腺癌は前立腺由来であることが判明し Endometrial carcinoma of prostate と呼称するのは適当でなく, Zaloudek らの Prostatic ductal adenocarcinoma with endometrioid feature とよぶのがより適切であると思われた。 なた治療に関しては抗男性ホルモンによ る治療も有効であり，通常の前立腺癌と同じ治療法でよいと思われた。
}

はじめに

前立腺乳頭状腺癌は1967年 Melicow と Pachter ${ }^{1)} に$ より, 乳頭状に増殖し, その形態が子宮内膜腺癌と類 似することから男性子宮由来の“Endometrial carcinoma of prostatic utricle”として報告された。その ためこのような前立腺乳頭状腺癌の治療には，抗男性 ホルモン療法は禁忌とされた。しかし，その後前立腺
乳頭状腺癌にも男性子宮由来ではなく前立腺小管由来 のものがあるとする報告が多くみられるよらになっ $た^{223)}$ 。

今回，われわれは前立腺乳頭状腺癌と診断された 5 例について，その臨床経過と前立腺特異抗原に対する 免疫組織学的検討ならびに電顕的検討を行い, 診断, 治療について文献的考察を行った。 
表 1 乳頭状腺癌の臨床所見

\begin{tabular}{|c|c|c|c|c|c|c|c|c|}
\hline Case & 主訴 & 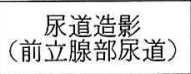 & $\begin{array}{l}\text { Acid-P } \\
\text { PAP }\end{array}$ & 生検 & 直腸診 & $\begin{array}{l}\text { Acinar type } \\
の \text { 合 併 }\end{array}$ & 治 療 & 予 後 \\
\hline 1. $\underset{72 \mathrm{y} .}{\mathrm{S} .} \mathrm{O}$. & $\begin{array}{l}\text { 肉眼的 } \\
\text { 血尿 }\end{array}$ & 不規則 & 正常 & $\mathrm{BPH}$ & $\mathrm{BPH}$ & - & $\begin{array}{r}\text { Retro + ホルモン } \\
\text { +放射線 }\end{array}$ & $\begin{array}{l}\text { 骨転移にて } \\
\text { 死亡(3y. } 3 \mathrm{~m} .)\end{array}$ \\
\hline 2. M. K. & $\begin{array}{l}\text { 肉眼的 } \\
\text { 血尿 }\end{array}$ & 延長・前傾 & 正常 & 施行せず & $\mathrm{BPH}$ & 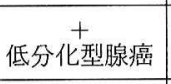 & Supra+放射線 & $\begin{array}{l}\text { 骨転移にて } \\
\text { 死亡(1y. } 8 \mathrm{~m} \text {.) }\end{array}$ \\
\hline 3. $\stackrel{\mathrm{Y}}{80 \mathrm{y} .} \mathrm{A}$. & $\begin{array}{l}\text { 肉眼的 } \\
\text { 血尿 }\end{array}$ & $\begin{array}{l}\text { 惩長・前傾 } \\
\text { 壁不整 }\end{array}$ & 正常 & 乳頭腺癌 & 硬結(+) & $\stackrel{+}{+}+\underset{n}{+}$ & $\begin{array}{r}\text { TUR+ホルモン } \\
\text { +放射線 }\end{array}$ & 生存(3y.) \\
\hline 4. $\underset{78 \mathrm{y} .}{\mathrm{J}}$. & 尿 閉 & $\begin{array}{l}\text { 狭小化 } \\
\text { 硬 化 }\end{array}$ & 正常 & 施行せず & $\mathrm{BPH}$ & - & Supra+ホルモン & 不 明 \\
\hline 5. $\begin{array}{l}\text { H. O. } \\
\text { (5y. }\end{array}$ & 排尿困難 & 陰影欠損 & 正常 & 乳頭腺癌 & 硬結(+) & $\underset{\text { 低分化型腺癌 }}{+}$ & TUR+ホルモン & 生存 $(6 \mathrm{~m})$. \\
\hline
\end{tabular}

\section{対象と方法}

対象症例は 5 例で，年齢は 55 歳 80 歳(平均 72.2 歳) である。

免疫組織学的検討は Peroxidase-antiperoxidase (PAP) 法にて Prostate-specific antigen (PSA) の染 色性をDAKO PAP KIT TMを用い検討した。パラフィ ン切片を脱パラ後, 内因性ペルオキシターゼを阻止し, swine serum で非特異的染色を減少させた。ついで抗 ヒトPSA 抗体と20分間インキュベーション，その後 抗ラビット Swine antiserumと30分インキュベー ション，ついで Peroxidaserabbit antihorseradish Peroxidase complex と30分インキュベーションし， Diaminobenzidine にて発色させ，へマトキシリンに て染色を行った。杂た, 5 例中 1 例に電顕的観察を行っ た。

\section{結 果}

1）臨床所見（表 1 )

主訴は 5 例中 3 例が肉眼的血尿で 1 例が尿閉， 1 例 が排尿困難であり，尿道造影では 1 例を除さ前立腺部 尿道の硬化，下規則，陰影欠損像等を認めた。総酸性 フォスファターゼあるいは，前立腺性酸性フォスファ ターゼ (PAP) は全例正常であった。直腸診では 5 例 中 2 例に硬結を認め, 生検は硬結をふれた 2 例を含む 3 例に行われ 1 例は $\mathrm{BPH}$, 硬結をふれた 2 例は, 乳頭 状腺癌の診断であった。術前診断は $\mathrm{BPH}$ が 3 例, 前立 腺癌 2 例であった。治療として全例に手術が行われ， 抗男性ホルモン療法は 4 例に, 放射線療法 (5,000 rads) が 3 例に行われていた。手術の内訳は TUR-P 2 例, 恥 骨上式前立腺摘出術 2 例, 恥骨後式前立腺摘出術 1 例 であった。抗男性ホルモン療法は diethylstilbestorol diphosphate, chrolmadinone acetate, estramustine phosphateが投与されていた。
図 1 Case 2. 広く明るい細胞質と比較的異型性の強 い核からなる腫瘍細胞が一層飞配列して和り刷子縁 は認められない（H.E 染色, $\times 200)$

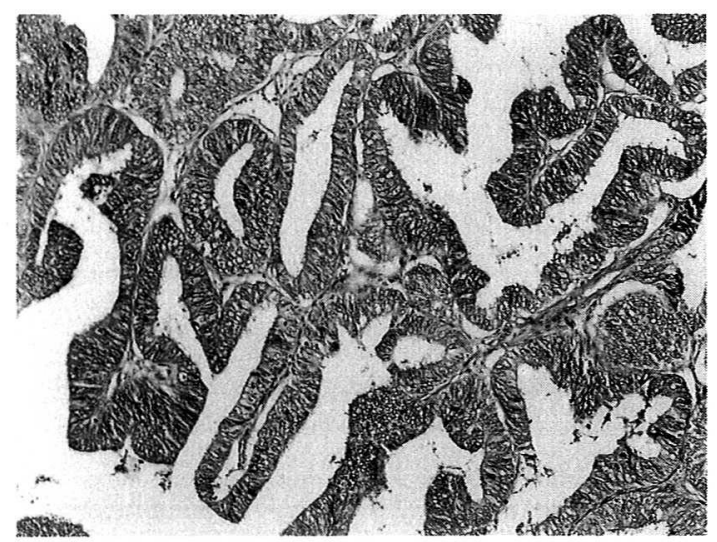

予後は 5 例中 2 例がそれぞれ 39 カ月，20カ月で骨転 移のため死亡， 2 例は術後 36 力， 6 カ月の現在転移 等の徴候はなく生存， 1 例は不明であった。

2) 組織学的所見

a) H.E. 染色

5 症例とも主な組織構築は乳頭状増殖を呈する腺癌 であり，このうち Case 2，3，5の 3 例で acinar type の癌が併存し Case 2，5は低分化，Case 3では高分化 腺癌であった。

乳頭状腺癌の組織所見として Case 2のごとく広く 明るい細胞質と比較的異型性の強い核からなる腫煌細 胞が一層に配列しており刷子縁は認めないものと（図 1), Case 4のごとく暗い好塩基性の細胞質と大きさの よく似た核をもつ腫瘍細胞が多層になって配列し刷子 縁が観察されるもの(図 2)に大別され, Case 1と Case 5は前者の所見に類似し, Case 3は後者の所見に類似し 
ていたが刷子縁は認めなかった。

b) PSA 免疫染色（図 3 ）

すべての症例に拈いて乳頭状腺癌の部分にPSA 陽 性像を認めたがその程度は各症例で差が認められた。 また陽性細胞と陰性細胞が混在していた。

c) 電顕所見（図 4 ）

図 2 Case 4. 暗い好塩基性の細胞質と大きさのよく 似た核をもつ腫瘍細胞が多層になって配列し刷子縁 が観察される。（H.E 染色, ×200）

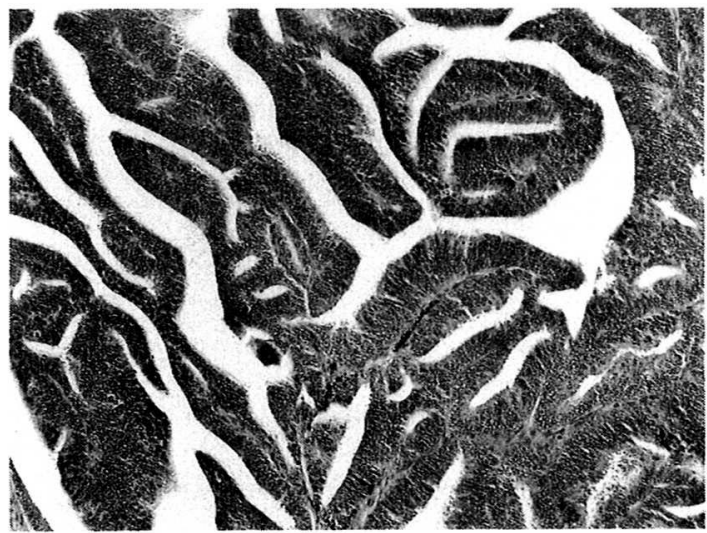

リピッド，分泌性空胞，ライソゾームを含む明るい 円柱細胞で, 細胞質に多くの空胞化がみられ, さらに 大きな核と明瞭なる核小体をもっていた。また暗細胞 は空胞はほとんどなく比較的電子が密な細胞質をもっ ていた。

\section{考 察}

Melicow \& Pachter')により報告された前立腺乳頭 状腺癌は, その発生母地から考光, 通常の前立腺癌に

図 3 Case 2. PSA がほぼ全体に染色されている. $(\mathrm{ABC}$ 染色, $\times 100)$

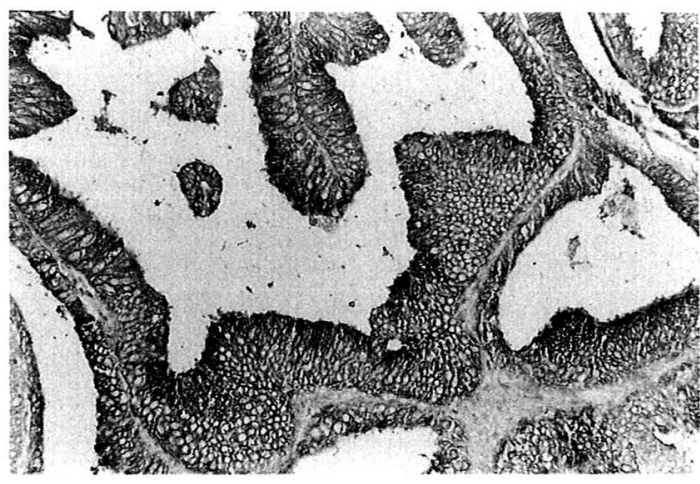

図 4 リピッド，分泌性空胞，ライソゾームを含む明るい円柱細胞で，細胞質に多く の空胞化がみられ，さらに大きな核と明瞭なる核小体をもっている。 また暗細胞は 空胞はほとんどなく比較的電子が密な細胞質をもっている. (右 $4,000 \times$, 左 $8,000 \times$ )
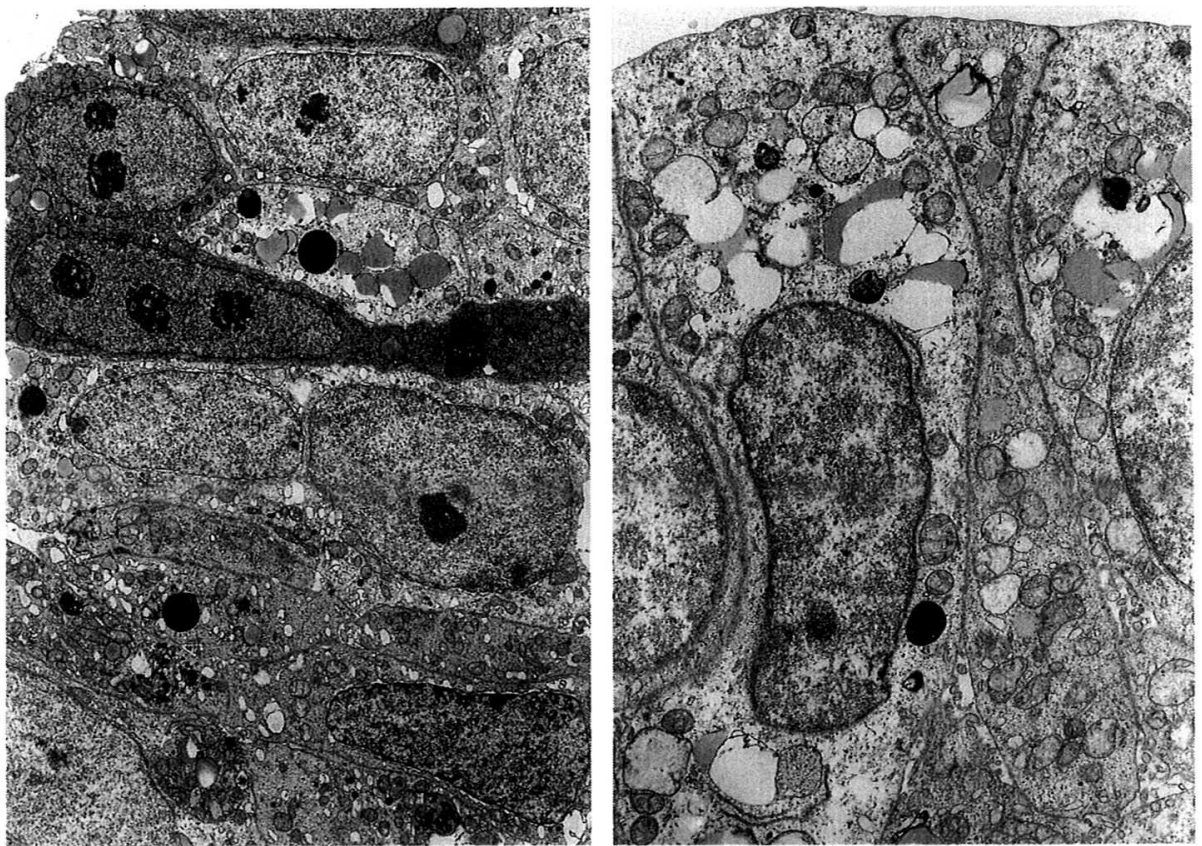
有効である除孟術や抗男性ホルモン療法を行らと逆効 果であるとされてきた。しかし，臨床上，乳頭状腺癌 と診断された症例で除辠術により前立腺の縮小をみた り，さらには転移巣の改善をみたといら報告が散見さ

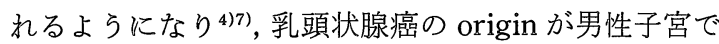
あるといら仮説に疑問がもたれるよらになり，除辠術 が有効であった症例では acinar type の癌を合併して いるのではないかとも推測された。しかし，Dube ら゙) は乳頭状腺癌が前立腺小管中に in situ に存在するこ とを確認し，さらにはPSA やPAPによる免疫組織学 的検討からも乳頭状腺癌が前立腺由来であるという証 明がなされている6) 8)。また，電顕像に打いても，1） Well-developed glands with distinct basal lamina,

2) Luminal micro villi, 3) Large nuclei with prominent nucleoli, 4) Desmosomes, 5) Secretory droplets, 6) Lysosomes, 7) Abundant rough endoplasmic reticulum 等の所見から子宮内膜癌とは全く異な り，やはり前立腺由来と報告されている25)。その名称 についても Melicowらの唱えた endometrial carcinoma of prostatic utricle に対し Zaloudek $ら^{21}$, Bostwick $ら^{5)}$ は prostatic ductal adenocarcinoma with endometrioid featuresあるいは endometrioid carcinomaとよぶべきであると報告して抢り， Walker $5^{8)}$ も従来使われていた endometrial adenocarcinoma といら呼称はさけるべきであるとの ベ，さらに，Dube ら²，Zaloudek ら²1はそれぞれ表 2 のような分類を提唱している。

以上のことをふまえ前立腺乳頭状腺癌の診断, 治療 等について文献的に検討した。

まず頻度であるが，本邦では原著として報告されて いるのは一条ら ${ }^{9 /}$ の報告以来, 自験例を含め 10 例 $^{10) ~ 13) ~}$ と少ない。しかし Dube ら ${ }^{3)} 4$,286例の前立腺癌を再 検討し，55例 (1.3\%) に purely ductal adenocarcinoma が, 207例 (4.0\%) に acinar type と ductal type の混合例が発見されたとしている。したがって乳 頭状腺癌は前立腺癌の $6.3 \%$ にみられたことになるが, 精阜のみに局在する乳頭状腺癌に限るとその頻度は $0.2 \sim 0.8 \%$ と報告されている。通常の前立腺癌との合 併について, Walther らは16例の集計のうち 6 例， Bostwick ら5)は13例中10例に認められたと報告して いるが，本邦での 10 例では 4 例に認められている。年 齢は70歳前後とされ, 本邦平均も69.4歳であった。

症状は排尿困難と血尿が多く, 通常の前立腺癌と比 較して血尿の割合が多いのが特徵と思われる。本邦報
表 2

1) Dube の分類

Type 1 : Ordinary acinar carcinoma

Type $2:$ pure ductal adenocarcinoma (Primary or secondary)

Type 3 : mixed acinar and ductal carcinoma

2) Zaloudek の分類

1. Adenocarcinoma of acinar origin.

2. Carcinoma of ductal origin.
A. Primary ductal carcinoma
B. Secondary duct adenocarcinoma
C. Ductal adenocarcinoma with endometrioid features
D. Transitional carcinoma
E. Squamous carcinoma
3. Carcinoma of undetermined origin.
A. Extensive carcinoma
B. Poorly differerentiated or undifferentiated carcinoma
C. Adenoid cystic

告例では 10 例中 4 例が肉眼的血尿であった。直腸診所 見はDube ら゙は acinar typeの癌の合併を除いた pure ductal carcinoma のらち primay duct 由来のも のでは4/8（50\%）が良性と診断されたが secodary duct 由来の 47 例ではわずか 4 例の及が良性と診断さ れたにすぎないと報告している。また Bostwick ら5)は 13例中 10 例に前立腺腫大を認め, そのらち 3 例に硬結, 5 例に前立腺全体が硬く触診されたと報告している。 本邦では10例中 6 例が $\mathrm{BPH}$ と診断されていた。膀胱 尿道鏡では Walther らは16例の集計例で精阜を含ん で乳頭状腫瘍を認めるものが 8 例, 精阜が正常で他部 位に乳頭状腫瘍を認めたもの 7 例と報告しており,

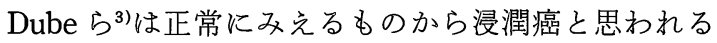
ものまで様々なタイプが存在するとしている。

血清前立腺性酸性フォスファターゼに関しては注と んどが正常であり，転移例にの久上昇するとされてい る。本邦例でも 1 例を除きすべて正常であった。鑑別 診断としては前立腺の移行上皮癌, ectopic prostatic tissue, 増殖性乳頭状尿道炎, inverted papilloma 等が あげられる。

治療は，手術療法としてはTUR-P が最も多く、放射 線治療, 抗男性ホルモン療法も多く行われている。 Walther らが集計した16例のらち男性子宮由来とし た症例の報告で積極的に progesterone を投与したの は 1 例のみで，その症例も放射線療法を併用している ため progesterone のみの効果は不明である。予後に関 
しては通常の前立腺癌と比べ良いというものからむし ろ悪いとするものまでさまざまである.

Dube らは secondary duct adenocarcinoma で 5 年 follow-up できた症例の33例のうち32例が estrogen 治療をうけ 5 年生存率は $24.2 \%$ であ，その予後は組 織学的異型度と転移の有無によく相関したと報告して いる.

病理組織診断所見として一般的には小管由来は乳頭 状増殖に分岐が多く, 単層の高円柱上皮で被われ, 細 胞質はあかるく単一の核を細胞基底部にもつとされて いる。 また男性子宮由来のそれは乳頭状増殖に分岐が 少なく, 数層の高円柱上皮で被われ, 細胞質は暗く, 大きな核を通常の位置にもつとされている3111). われ われの症例では小管由来と思われる Case 2 子子宮由 来と思われる Case 5 がありその他は典型的な所見は なくその両者の移行型をしめしており組織型のみで小 管由来か男性子宮由来かを明確に区別することはでき なかった。

前立腺乳頭状腺癌は男性子宮由来よりは前立腺小管 由来のものが多く, その予後も通常の前立腺癌とほぼ 同じであり, 治療は acinar type の癌と同様に扱って もよいと思われる。ささらに男性子宮はやはり estrogen dependent な組織であるという説に疑問をもつ多くの 解剖学者が存在し, 彼らは男性子宮上皮は早期にUrogenital sinus (ectoderm)によりおきかわっていると 反論している ${ }^{14)}$ 。をた Bostwick は 2 例の正常成人男 性子宮をPSA, PAPで染色し 2 例ともに陽性に染色 されたとしている。また乳頭状腺癌の PSA の免疫組 織染色に扔いて腫瘍細胞は一様に染色されず positive 細胞と negative 細胞があり,それは腫瘍の heterogeneity を示すものと想像されている68).ささらに乳頭 状腺癌のホルモン感受性についての報告もみあたらな い.

以上のことからまだまだ不明瞭な部分が多いものの 乳頭状腺癌はまず ductal origin と考学る方が一般的 であり, 乳頭状腺癌の診断を得た場合, まず PSA, PAPの免疫組織染色をおこない陽性であることの証 明, H.E. 標本に拈ける小管内の in situ component の 存在, さらには膀胖尿道鏡にて精阜が正常なことなど の確認ができればその stage に応じた通常の前立腺癌 の治療を行らべきであると思われた。そして Bostwick らが述べている「男性子宮由来と前立腺小 管由来の乳頭状癌は病理学的にも臨床学的にもなんら 差を認めず，従来考兄られたより予後もあまり良くな
いと思われた」といら結論にわれわれも同意したい。

$$
\text { 文献 }
$$

1) Melicow, M.M. and Pachter, M.R.: Endometrial carcinoma of prostatic utricle (Uterus mesculinus). Cancer, 20, 1715-1722, 1967.

2) Zaloudek, C., Williams, J.W. and Kempson, R. L. : Endometrial adenocarcinoma of the prostate. A distrinctive tumor of probable prostatic duct origin. Cancer, 37, 2255-2262, 1976.

3) Dube, V.E., Farrow, G.H. and Greene, L.F.: Prostatic adenocarcinoma of ductal origin. Cancer, 32, 402-409, 1973.

4) Young, B.W. and Lagios, M.D.: Endometrial (Papillary) carcinoma of the prostatic utricle, Response to Orchiectomy. A case Report. Cancer, 32, 1293-1300, 1973.

5) Bostwick, D.G., Kindrachuck, R.W. and Rouse, R.V.: Prostatic adenocarcinoma with endometrioid features. Clinical, pathologic and ultrastructural findings. Am. J. Surg. Path., 9, 595-609, 1985.

6) Kuhajida, F.P., Gipson, T. and Mendelshon, G.: Papillary adenocarcinoma of the prostate. An immunohistochemical study. Cancer, 54, 1328-1332, 1984.

7) Walther, M.M., Nassar, V., Harruff, R.C., Mann, B.B. Jr., Finnerty, D.P. and HewenLowe, K.O.: Endometric carcinoma of the prostatic utricle : A tumor of prostatic origin. J. Urol., 134, 769-773, 1985.

8) Walker, A.N., Mills, S.E., Fechner, R.E. and Perry, J.M.: 'Endometrial' Adenocarcinoma of the prostatic urethra arising in a villous polyp. Arch. pathol. Lab. Med., 106, 624-627, 1982.

9）一条貞敏, 伊達智徳, 今村 晸: 前立腺乳頭腺癌の 1 例. 日泌会誌, 67, 201-204, 1976.

10）福岡 洋, 出崎 彰, 北村 創：前立腺乳頭腺癌の 1 例. 泌尿紀要, $30,663-669,1984$.

11）宇山 健, 山本 洋, 森脇昭介: 前立腺乳頭腺癌の 1 例. 西日泌尿，39，361-368，1977.

12）清水芳幸, 徳原正洋: 前立腺已頭腺癌の 1 例. 西日 泌尿, 44, 113-116, 1982.

13）鄉司和男, 田 珠相, 浜見 学, 守殿貞夫, 斉藤 博, 未光 浩: 前立腺乳頭腺癌の 1 例. 泌尿紀要, 32, 113-118, 1986.

14) McNeal, J.E.: The prostate and prostatic urethra: A morphologic synthesis. J. Urol., 107, 1008-1016, 1972.

15) Langman, J.: In Medical Embryology (3rd ed.) Williams \& Wilkins, Baltimore, 1975, p. 181. (1987年 9 月 1 日受理) 